\title{
Sistem Kontrol Tingkat Kekeruhan Pada Aquarium Menggunakan Arduino Uno
}

\author{
Muhammad Syaif Ramadhan, Muhammad Rivai \\ Departemen Teknik Elektro, Fakultas Teknologi Elektro, Institut Teknologi Sepuluh Nopember \\ E-mail: syaifjago@yahoo.co.id, muhammad_rivai@ee.its.ac.id
}

\begin{abstract}
Abstrak-Ikan berisiko terkena dampak buruk apabila menetap pada air keruh yang terekspos partikel halus. Peningkatan kekeruhan dapat berdampak pada penurunan tingkat harapan hidup embrio telur ikan. Pada penelitian ini telah dibuat suatu sistem yang dapat mengatur kekeruhan aquarium dengan memanfaatkan Turbidity Sensor. Sensor ini mempunyai ukuran kecil, dan praktis, serta kompatibel dengan mikrokontroler Arduino Uno. Output data analog dari sensor dikonversi oleh Analog to Digital Converter pada Arduino Uno menjadi data digital yang merepresentasikan tingkat kekeruhan. Kekeruhan akan dikendalikan oleh sistem dengan metode kontrol proporsional. Ketika kekeruhan diatas nilai yang dikehendaki, maka motor pompa akan mendapatkan perubahan Pulse Width Modulation (PWM) untuk mempercepat proses penyaringan. Pada pengujian yang dilakukan di aquarium menunjukkan bahwa pompa memiliki rentang debit antara 96,48 dan $120,96 \mathrm{~mL} / \mathrm{sec}$ saat sensor menerima tingkat kekeruhan antara 0 dan $25 \%$. Hasil pengujian sistem keseluruhan menunjukkan bahwa adanya penurunan kekeruhan dari $5,76 \%$ menjadi $2,14 \%$ dalam waktu 15 jam.
\end{abstract}

Kata Kunci-Arduino Uno, Kekeruhan Air, Kontrol Proporsional, Turbidity Sensor.

\section{PENDAHULUAN}

$\mathrm{P}$ ENELITIAN di laboratorium dan di lapangan menunjukkan penurunan survival rate embrio telur ikan ketika terjadi kenaikan partikel halus penyebab kekeruhan (ukuran kurang dari $6 \mathrm{~mm}$ ) sebesar $5-10 \%$ pada tempat bertelur ikan (spawning nest). Kekeruhan tersebut menyebabkan kematian telur ikan karena menghalangi pertukaran gas, dan pembuangan sisa metabolism [1].

Ikan dikelompokkan berdasarkan habitat air dingin (dibawah $20^{\circ} \mathrm{C}$ ), dan air hangat (diatas $20^{\circ} \mathrm{C}$ ) [2]. Toleransi ikan air hangat terhadap kekeruhan lebih tinggi (25 NTU) dibandingkan ikan habitat air dingin (10 NTU) [3]. Pada umumnya ikan dewasa dapat mentoleransi kekeruhan tinggi. Kematian pada ikan dewasa hanya ditemukan pada kekeruhan yang sangat tinggi dan umumnya tidak ditemukan di sungai (di atas $100000 \mathrm{mg} / \mathrm{L}$ ). Tetapi untuk ikan yang baru menetas akan mati pada kekeruhan yang jauh lebih rendah (100-1500 mg/L) [1].

European Inland Fisheries and Aquaculture Advisory Commission (EIFAAC) menerangkan akibat dari partikel halus penyebab kekeruhan pada ikan air tawar yaitu: menyebabkan kematian pada ikan, mengurangi tingkat pertumbuhan, mengurangi ketahanan terhadap penyakit, mencegah keberhasilan pengembangan telur dan larva ikan; serta mempengaruhi pergerakan dan migrasi alami ikan [3].

Kontrol proportional-integral-derivative (PID) sering digunakan untuk mengatur kadar larutan [4]. Pada penelitian ini penulis melakukan pengontrolan kadar suatu zat terlarut berupa partikel halus dari pakan ikan. Kontrol proporsional digunakan karena lebih mudah, dan praktis serta sudah cukup handal untuk melakukan pengendalian kekeruhan aquarium. Sistem yang dikembangkan ini diharapkan dapat mengatur tingkat kekeruhan pada aquarium sehingga dapat menaikkan tingkat harapan hidup ikan.

\section{DASAR TEORI}

Kontrol proporsional merupakan bagian dari kontroller PID dimana nilai $\mathrm{Ki}$, dan $\mathrm{Kd}$ adalah 0 . Kontrol PID adalah sebuah kontroller pada sebuah sistem instrumentasi dimana terdapat elemen feedback didalamnya. Komponen PID terdiri dari proportional (P), derivative (D) dan integral (I). Ketiganya dapat digunakan secara bersamaan ataupun sendiri-sendiri tergantung pada respon yang diinginkan dalam sebuah plant [5]. Kontrol proporsional melakukan koreksi pada variabel terkontrol yang sebanding dengan perbedaan nilai yang diinginkan (set point) dan nilai yang terukur (input value). Dengan kata lain, output dari kontrol proporsional adalah produk perkalian dari sinyal error dan nilai gain proporsional. Secara matematis kontrol proporsional dapat dirumuskan sebagai persamaan (1).

$$
\text { Output }=\text { Kp x (Setpoint }- \text { Input })
$$

Penguat operasional atau operational amplifier (op amp) adalah rangkaian terpadu yang dapat digunakan sebagai rangkaian buffer, penjumlah, integrator, differentiator, comparator, konverter impedansi negatif, zero cross detector dan lain sebagainya [6]. Pada penelitian ini op amp digunakan sebagai rangkaian pengkondisi sinyal atau signal conditioner yang terdiri atas rangkaian pengurang (subtractor), penguat tak membalik (non-inverting amplifier) dan penyangga tegangan (buffer).

Sensor adalah alat untuk mendeteksi atau mengukur suatu pengukuran dari besaran analog yang bersifat mekanis, kimiawi, dan lainnya menjadi besaran listrik seperti tegangan dan arus listrik. Tingkat kekeruhan diukur dengan menentukan kejernihan air berdasarkan jumlah cahaya yang melewati kotoran penghalang di dalam air yang berupa partikel halus [7]. Partikel halus akan mengeruhkan air terutama zat padat transparan seperti kaca dan plastik. Partikel halus juga berasal dari mahluk hidup seperti plankton, dan partikel organik lainnya. Penelitian ini menggunakan modul sensor kekeruhan SEN1089 dimana hubungan antara tegangan hasil pembacaan (volt) dengan kekeruhan (NTU) bergantung pada jumlah partikel padat terlarut atau Total Suspended Solid (TSS) yang terdapat 
diantara sensor cahaya dan sumber cahaya yang terpasang pada modul sensor tersebut.

Pompa air diletakkan di dalam aquarium berfungsi untuk mengalirkan air ke dalam box filter yang diletakkan diatas aquarium dan selanjutnya air akan dikembalikan ke aquarium. Pada pengoperasiannya, pompa air akan diatur oleh mikrokontroller Arduino Uno dengan menggunakan komponen switching berupa modul Solid State Relay (SSR). SSR merupakan jenis relay yang tidak memiliki kumparan atau kontak sesungguhnya, sebagai gantinya digunakan semikonduktor seperti transistor bipolar, MOSFET, SCR, atau TRIAC [8]. SSR merupakan perangkat switching elektronik yang mengalihkan daya dari rangkaian pengontrol ke rangkaian beban, dan memiliki mekanisme pengendalian dengan cara coupling untuk mengaktifkan sinyal kontrol. Pada penelitian ini digunakan SSR dengan coupling secara optik yang memiliki keuntungan berupa sensitivitas berkisar antara 6 sampai 100 milliwatt. SSR tipe ini juga kompatibel dengan TTL logic level dan dapat di-drive secara paralel oleh high-fan-out logic data line [9].

Arduino Uno adalah sebuah board mikrokontroler berbasis ATmega328. Board ini memiliki 14 pin input/output digital (6 pin dapat digunakan sebagai output PWM), 6 pin input analog, resonator keramik (crystal) 16 $\mathrm{MHz}$, koneksi USB, colokan listrik (power jack), header ICSP, dan tombol reset. Arduino ini akan bertindak sebagai pemroses utama dari sistem dalam menjalankan tugas mengolah data tegangan sensor, menggunakan ADC, menerapkan kontrol proporsional, menampilkan informasi pada LCD, serta mengatur kecepatan pompa dengan PWM.

\section{PERANCANGAN SISTEM}

Perancangan sistem dibagi menjadi 3 bagian yaitu sensor, kontroler proporsional, dan aktuator. Pada gambar 1 menunjukkan diagram blok sistem. Input dari sistem berupa nilai penunjukan tegangan sensor kekeruhan yang dikondisikan dengan rangkaian signal conditioner. Setting point pada sistem merupakan nilai tegangan sensor saat air dalam kondisi jernih yang ditentukan sebelumnya. Arduino melakukan fungsi pengolahan data, proses ADC dan fungsi kontrol proporsional. Output dari arduino akan memberi sinyal PWM pada modul SSR yang akan mengaktifkan pompa filter mekanik untuk menyaring zat padat terlarut. Ketika kekeruhan di bawah nilai setting point (semakin keruh air, semakin rendah tegangan pembacaan, begitu pula sebaliknya) maka pompa filter mekanik akan dipercepat untuk menyaring zat padat terlarut (suspended solid).

Gambar 2 menunjukkan diagram blok perangkat keras sistem. Mikrokontroler Arduino Uno digunakan sebagai unit pengakuisisi data, pemrosesan data, dan pengeksekusi metode kontrol proporsional. Sensor kekeruhan SKU SEN0189 berfungsi untuk mengukur kekeruhan di dalam air. Rangkaian signal conditioner mengkondisikan tegangan keluaran dari sensor. Solid State Relay (SSR) digunakan sebagai relay dengan input PWM untuk mengontrol kecepatan motor pompa filter mekanik.

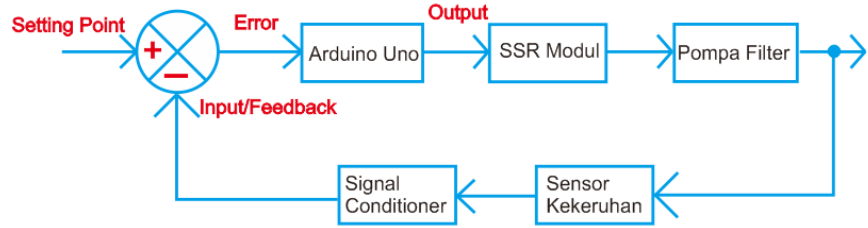

Gambar 1. Diagram blok sistem

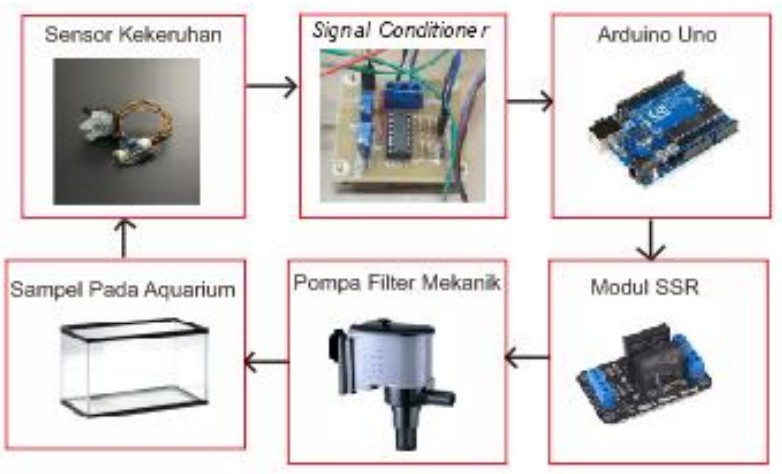

Gambar 2. Diagram blok perangkat keras.

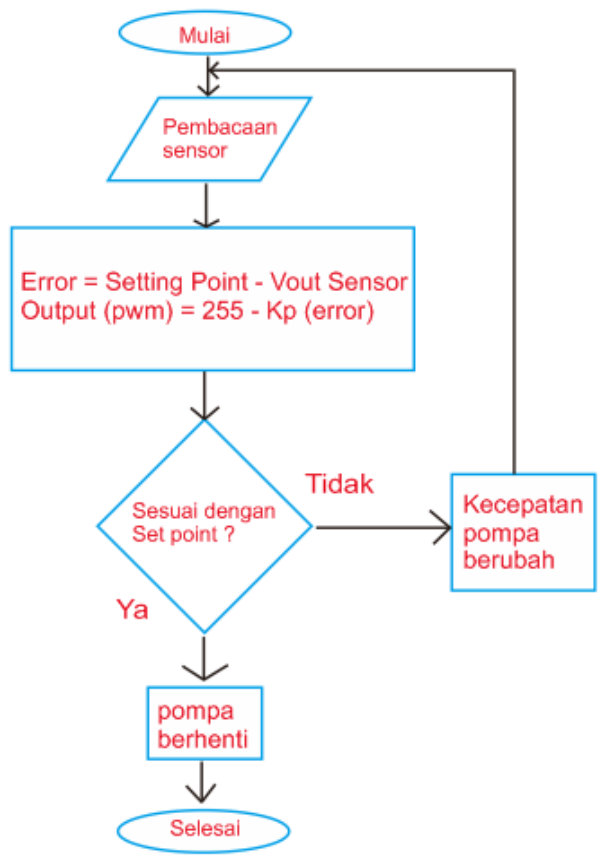

Gambar 3. Alur kerja sistem

LCD 16x4 dilengkapi modul komunikasi I2C berfungsi sebagai monitor untuk menampilkan nilai kekeruhan di dalam air, tegangan error, PWM bit pompa filter, dan duty cycle pada pompa. Pompa filter mekanik sebagai alat untuk menyaring air ke dalam box filter yang berisi penyaring partikel sehingga dapat mengurangi kadar kekeruhan.

Gambar 3 menunjukkan alur kerja sistem. Langkah awal yang dilakukan sistem adalah membaca nilai kekeruhan awal oleh ADC pada mikrokontroler arduino yang memiliki resolusi 10 bit. Data digital yang dihasilkan ADC akan masuk pada proses kontrol proporsional dimana error adalah nilai setting point dikurangi nilai pembacaan dari tegangan output sensor. Selanjutnya nilai error akan dikalikan dengan nilai konstanta proportional (Kp) dan dikurangkan dengan nilai output maksimum PWM yaitu 255. Hal ini dilakukan karena SSR yang digunakan bersifat active low. 


\section{PENGUJIAN DAN ANALISIS}

Pengujian sensor kekeruhan SKU SEN0189 dilakukan untuk mengetahui karakteristik sensor, melakukan kalibrasi, dan mencari rentang nilai output sensor yang akan diakuisisi oleh ADC. Pengujian ini meliputi air bersih yang akan ditampung di wadah berupa gelas, serta dicampurkan dengan pakan ikan hias. Pakan ikan hias dipilih sebagai sampel, karena pemberian pakan yang terlalu banyak akan mengeruhkan air aquarium. Terdapat beberapa masalah yang dihadapi, yaitu sensor yang peka dengan cahaya di lingkungan sekitar, serta ketidakstabilan dari nilai pengukuran yang disebabkan pergerakan partikel padat terlarut di dalam air yang dinamis. Untuk mengatasi masalah tersebut maka sensor ditutup menggunakan pipa berwarna hitam agar tidak menerima cahaya dari lingkungan, dan dilakukan pengukuran secara dinamis. Pengujian secara statis dilakukan untuk mengetahui kalibrasi sensor berupa hubungan tegangan keluaran sensor dengan nilai kekeruhan seperti yang ditunjukkan tabel 1, dan gambar 4. Pengukuran secara dinamis dilakukan secara langsung saat partikel halus belum bercampur. Hasil pengukuran secara dinamis ditunjukkan pada gambar 5.

Pengujian pompa dilakukan untuk mengetahui seberapa banyak air yang dapat dialirkan dalam kurun waktu tertentu (debit air). Pengujian pompa dibagi menjadi 2 bagian, yaitu pengujian debit air terhadap PWM yang ditunjukkan pada tabel 2 dan gambar 6, dan pengujian debit air pompa terhadap sampel air campuran pakan ikan dengan kadar yang bervariasi yang ditunjukkan tabel 3 dan gambar 7 .

Tabel 1.

Pengujian sensor secara statis

\begin{tabular}{ccc}
\hline $\begin{array}{c}\text { Pakan Ikan } \\
(\text { gram })\end{array}$ & $\begin{array}{c}\text { Tegangan } \\
(\text { volt })\end{array}$ & $\begin{array}{c}\text { Kekeruhan } \\
(\%)\end{array}$ \\
\hline 0 & 3,8 & 0 \\
5 & 3,6 & 2,5 \\
10 & 3,55 & 5 \\
15 & 3,48 & 7,5 \\
20 & 3,36 & 10 \\
25 & 3,38 & 12,5 \\
30 & 3,27 & 15 \\
35 & 3,12 & 17,5 \\
40 & 2,96 & 20 \\
45 & 2,96 & 22,5 \\
50 & 2,96 & 25 \\
\hline \hline
\end{tabular}

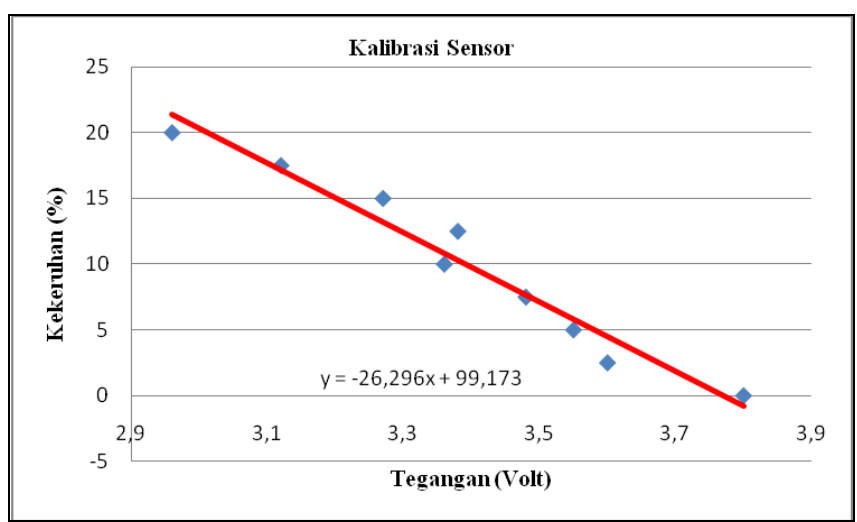

Gambar 4. Grafik kalibrasi sensor
Hasil percobaan menunjukkan bahwa debit air berbanding lurus dengan nilai dari PWM, dan kadar sampel pakan ikan. Hasil percobaan juga menunjukkan pompa tidak dapat dijalankan pada duty cycle dibawah $40 \%$ karena tidak dapat mengangkat air secara optimal.

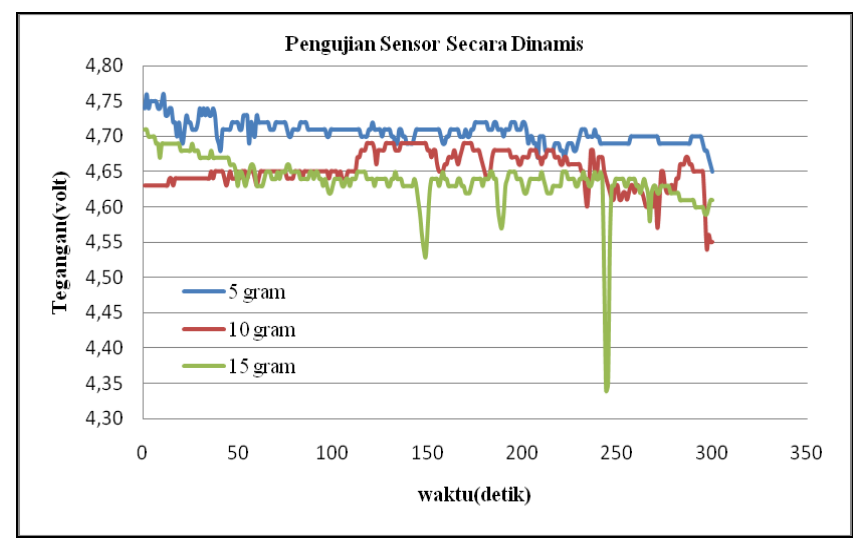

Gambar 5. Grafik pengujian dinamis sensor

Tabel 2.

Hasil pengujian Pompa terhadap PWM

\begin{tabular}{cc}
\hline $\begin{array}{c}\text { PWM Duty Cycle } \\
(\%)\end{array}$ & $\begin{array}{c}\text { Debit air } \\
(\mathrm{mL} / \mathrm{sec})\end{array}$ \\
\hline 40 & 90,72 \\
50 & 97,92 \\
60 & 111,6 \\
70 & 124,56 \\
80 & 122,4 \\
90 & 124,56 \\
100 & 116,75 \\
\hline
\end{tabular}

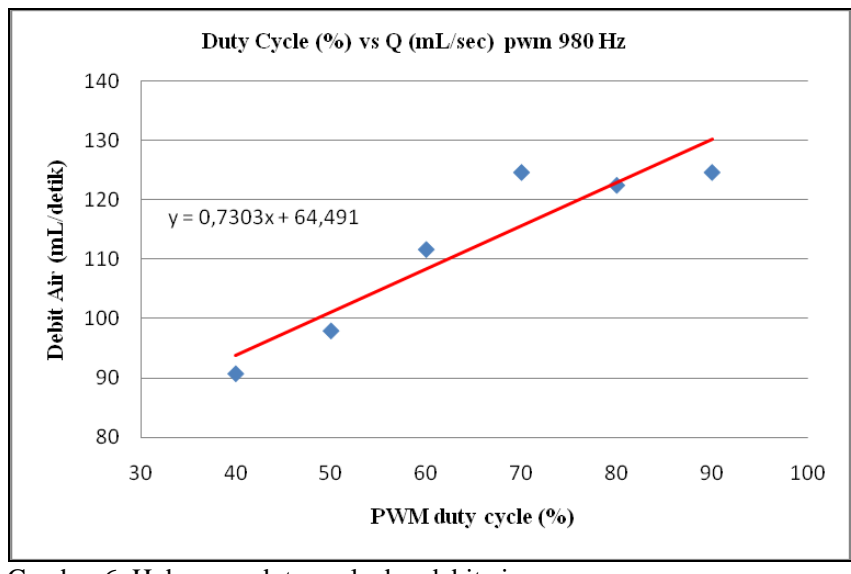

Gambar 6. Hubungan duty cycle dan debit air

Tabel 3.

Pengujian Pompa terhadap Sampel

\begin{tabular}{ccc}
\hline $\begin{array}{c}\text { Kadar Sampel } \\
(\text { gram })\end{array}$ & $\begin{array}{c}\text { Duty } \\
\text { Cycle }(\%)\end{array}$ & $\begin{array}{c}\text { Debit air } \\
(\mathrm{mL} / \mathrm{sec})\end{array}$ \\
\hline 0 & 40 & 100,8 \\
5 & 40 & 96,48 \\
10 & 40 & 100,8 \\
15 & 40 & 97,92 \\
20 & 40 & 99,36 \\
25 & 47 & 106,56 \\
30 & 61 & 110,88 \\
35 & 86 & 115,2 \\
40 & 96 & 120,96 \\
\hline \hline
\end{tabular}




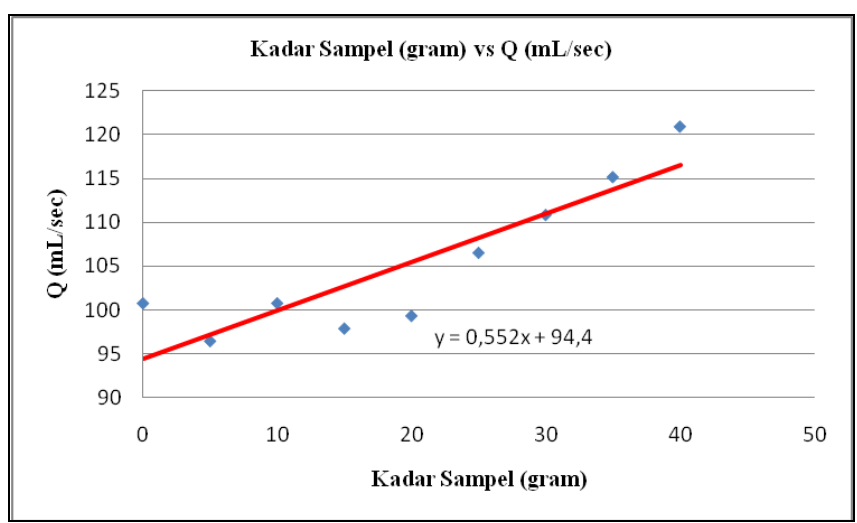

Gambar 7. Hubungan kadar pakan ikan dan debit air pompa

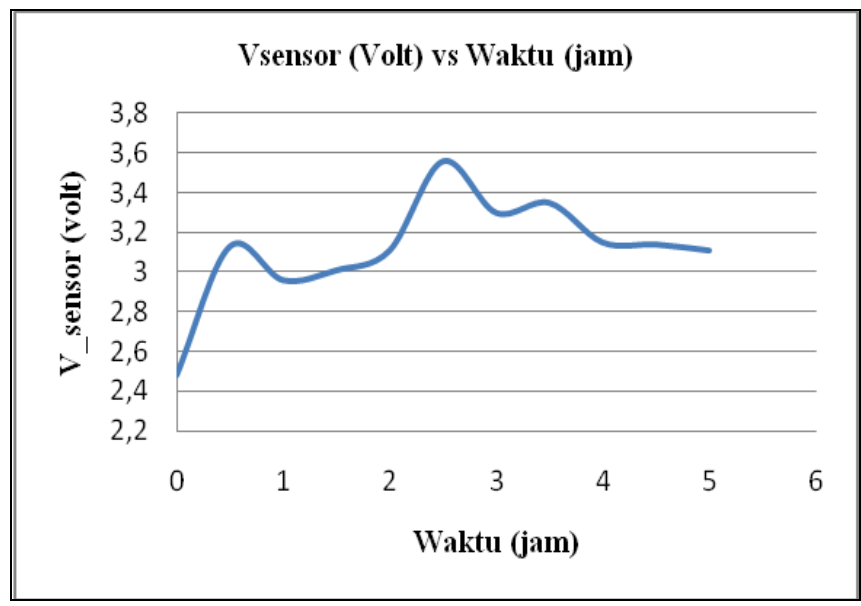

Gambar 8. Pengujian sistem setelah 10 menit

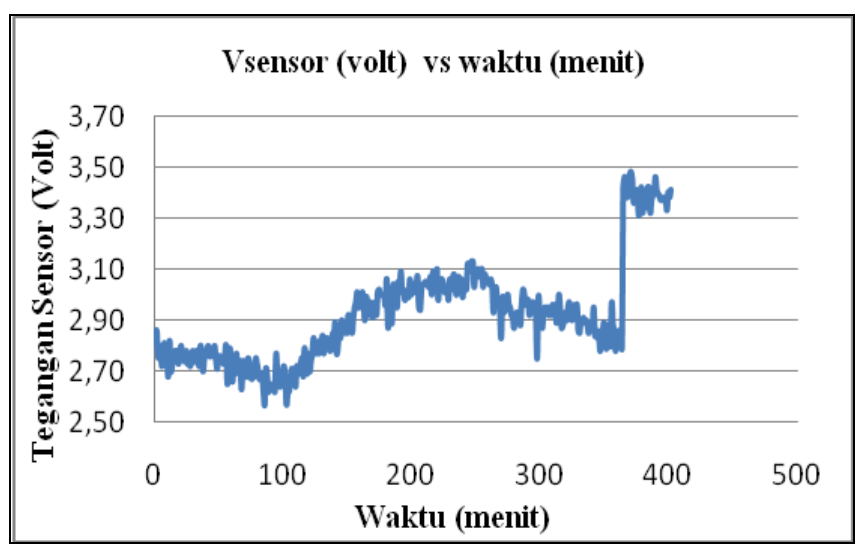

Gambar 9. Pengujian sistem setelah 10 jam

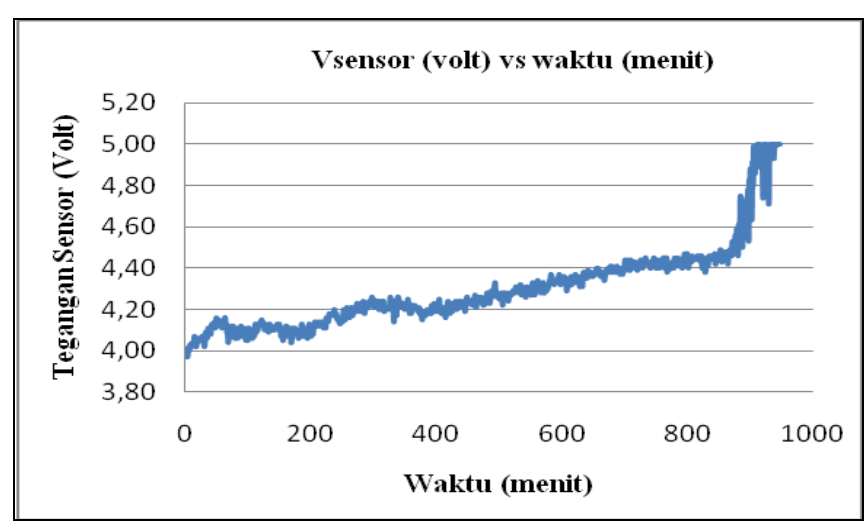

Gambar 10. Pengujian sistem setelah 24 jam

Pada pengujian sistem, mula-mula aquarium diisi dengan air bersih sejumlah 6 liter, kemudian dicampurkan 100 gram pakan ikan. Air diaduk dengan pakan ikan dan ditunggu beberapa saat agar keruh, kemudian sisa makanan ikan yang masih mengambang di permukaan dibuang. Setelah itu sistem dijalankan, dan dipantau setiap satu menit. Pengujian sistem dilakukan tiga kali dengan variasi durasi bercampurnya partikel halus dari pakan ikan dengan air pada aquarium. Partikel halus tersebut memerlukan waktu untuk dapat tercampur dengan baik serta untuk mengendapkan sebagian partikel yang berat di dasar aquarium. Variasi durasi waktu bercampurnya sampel yang digunakan yaitu 10 menit, 12 jam, dan 24 jam.

Gambar 8 menunjukkan hasil pengujian sistem setelah sampel dibiarkan 10 menit. Kenaikan tegangan sensor dari 2,48 volt (kekeruhan 12,02 \%) ke 3,11 volt (kekeruhan 9,37\%) memerlukan waktu 5 jam. Pengujian setelah sampel bercampur selama 10 jam ditunjukkan pada gambar 9 . Kenaikan tegangan sensor dari 2,81 volt (kekeruhan 10,63 $\%$ ) ke 3,41 volt (kekeruhan 8,11\%) memerlukan waktu 6,7 jam. Pengujian setelah sampel bercampur selama 24 jam yang ditampilkan pada gambar 10. Kenaikan tegangan sensor dari 3,97 volt (kekeruhan 5,76\%) hingga menjadi 4,83 volt (kekeruhan 2,14\%) memerlukan waktu 15,8 jam.

\section{KESIMPULAN}

Pada penelitian ini telah dibuat suatu sistem yang dapat mengatur kekeruhan aquarium dengan memanfaatkan Turbidity Sensor dan kontrol proporsional. Kalibrasi sensor menunjukkan sensor mampu mengukur kekeruhan dalam bentuk persentase pada rentang diantara 0 dan $20 \%$ yang diwakili tegangan sensor antara 3,0 dan 3,9 volt. Pada kekeruhan diatas $20 \%$ sensor tidak mengalami penurunan tegangan atau saturasi. Hasil pengujian debit air pompa, didapatkan hasil pompa memiliki rentang debit diantara 96,48 dan 120,96 mL/sec pada saat rentang kekeruhan antara 0 dan $25 \%$. Pengujian sistem secara keseluruhan yang dilakukan setelah sampel bercampur selama 24 jam menunjukkan adanya kenaikan tegangan sensor yang semula bernilai 3,97 volt (kekeruhan 5,76 \%) menjadi 4,83 volt (kekeruhan 2,14\%) memerlukan waktu 15,8 jam.

\section{DAFTAR PUSTAKA}

[1] K. . Robertson, M.J., Scruton, D.A., Gregory, R.S., Clarke, "Effect of Suspended Sediment on Freshwater Fish and Fish Habitat," Can. Tech. Rep. Fish. Aquat. Sci, p. 37, 2006.

[2] F. . Dauwalter, D.C., Fisher, W.L., Rahel, "Warmwater Streams," IFMNA, 2010

[3] Anonim, "Turbidity: Description, Impact on Water Quality, Sources, Measures," Minnesota Pollut. Control Agency, 2008.

[4] S. Muhammad Rivai, Suwito, M., Chondro, P., Ruan, "Design and Implementation of A Submerged Capacitive Sensor in PID Controller to Regulate the Concentration of Non-Denatured Ethyl Alcohol," in Seminar on Intelligent Technology and Its Applications, 2015.

[5] A. Nugraha, Z., M., Musyafa, "Perancangan Kontrol PID Untuk Mengatur Tingkat Kejernihan Air Pada Ssistem Pengolahan Air Bersih Skala Rumah Tangga," Institut Teknologi Sepuluh Nopember.

[6] H. Muhamad, M., Mahmad, H., Hussin, "Design of CMOS Zero Crossing Detector Utilizing 0.25 um Technology," in International Conference on Electronic Devices (ICEDSA2010), 2010.

[7] A. M. . Azman A.A., Rahiman M.H.F., Taib M.N., Sidek N.H., Bakar I.A.A., "A Low Cost Nephelometric Turbidity Sensor for Continual Domestic Water Quality Monitoring System," IEEE Int. Conf. Autom. Control Intell. Syst., 2016.

[8] M. R. Riadhi, L., "Sistem Pengaturan Oksigen Terlarut Menggunakan Metode Logika Fuzzy Berbasis Mikrokontroller 
Teensy Board,” ITS, 2017.

[9] K. Smitha, T.K., Ravikiran, B.A., Karthik, P., Mondal, T., "Design and Implementation of Control of Solid State Relay Switches Using MSP 430 for Instantaneous High Current Supply," in International Conference on Green Computing and Internet of Things (ICGC IoT), 2016. 